a fishing trip were apparently unable to understand the hazard warnings and wandered onto the island. Bacillus anthracis is particularly dangerous to humans when inhaled into the lungs - a low risk on Gruinard because the spores are buried in the soil. It can also enter the body through the gut or through cuts on the skin, when it causes spreading sores.

Officially Bacillus anthracis is described as a hypervirulent micro-organism which is difficult to destroy. In laboratory conditions it is susceptible to heat. Peracetic acid can also destroy anthrax spores but the acid must itself be carefully handled.

One knowledgeable person confessed himself perplexed as to why the Ministry of Defence is making such a fuss about the isiand. The strain of anthrax on Gruinard is not as virulent as some field strains and infection is easily treated with antibiotics. Animals can be vaccinated against the disease and in many areas, where the climate is less favourable, anthrax has been successfully eradicated through animal vaccination programmes. Gruinard Island, he said, poses no serious threat to humans. In the past anthrax has been found in animal bonemeal feed and its presence ignored.

Jane Wynn

\section{UK research councils \\ Sharing of spoils}

One of the long-standing sources of jealousy among British scientists is likely to be stirred up by the decision announced last week to mount an inquiry into the ways in which research councils distribute their resources between in-house research and support for universities. The Advisory Board for the Research Councils has set up a committee under Mr J.R.S. Morris, chairman of the British subsidiary of the oil-drilling company Brown and Root, to make recommendations on the subject early in 1983.

The committee is a swift response to one of the more contentious recommendations of the Merrison report on university research, published last month (see Nature 10 June, p.445). The report said that when research councils are under pressure, "university support may be the only or chief area" in which they can economize. In a judicious but ominous phrase, the report went on to say "we are not satisfied" that the balance between inhouse spending and university support "is always right',

The committee also pointed out that during the 1970s, when government support for the research councils increased by 8 per cent in real terms, the councils' collective support for university research increased by only 3 per cent. This comparison may, however, be misleading because of the importance of salary and equipment costs in in-house budgets and research grants respectively.
Even so, some research council employees see the setting up of the new committee as an attempt by the academic scientists who account for the majority of members of the advisory board to increase the funds available for university research. Others ruefully recall that in the $1960 \mathrm{~s}$, the Agricultural Research Council, relatively and absolutely the most modest supporter of university research, was, on account of its dependence on in-house research, the target of the complaints that led to the Rothschild reorganization of civil science.

In practice, the new committee will have to solve several awkward problems, not least that of deciding how to assess the present performance of the research councils. The accompanying chart, based on figures taken from the Merrison report, shows the use made of resources in 1978-79 by the four research councils supporting research in the natural sciences. The cost of commissioned research is that commissioned by government departments from the research councils under the Rothschild customer-contractor principle.

The pattern of spending by the Science

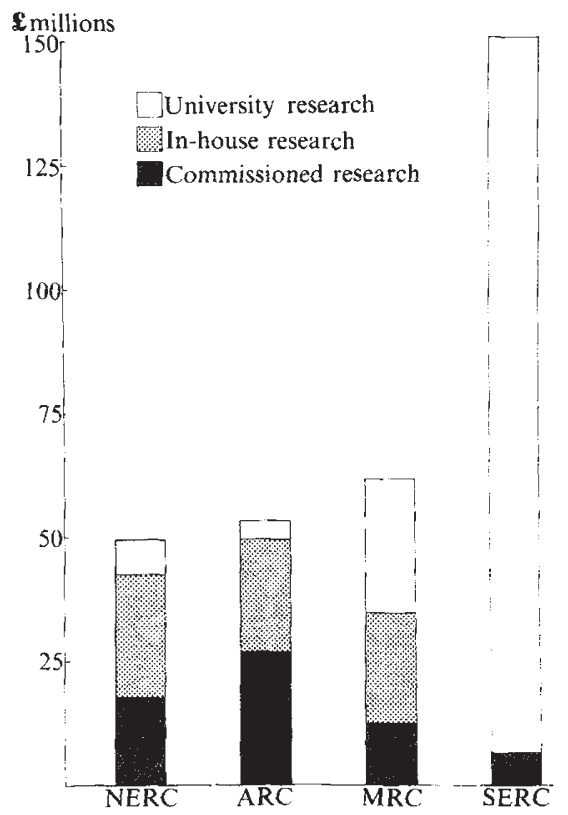

Research council spending, 1978-79. Spending by the Agricultural Research Council (ARC), Natural Environment Research Council (NERC), Medical Research Council (MRC) and Science and Engineering Research Council (MRC) and Science and Engineering
Research Council (SERC). Source: Cmnd 8567, HMSO.

and Engineering Research Council is anomalous in that, of the $£ 144$ million claimed as university support in 1978-79, only $£ 51$ million was spent directly in universities, with the remainder divided almost equally between service laboratories and subscriptions to international projects.

For the committee (which will have met for the first time this Wednesday, 4 August), the most difficult task will be to establish criteria for deciding how the "right" balance between in-house research and university support should be struck. The chairman of the committee is thought to be impartial in the sense of being as impatient with the research councils as with academics.

\section{Telecommunications}

\section{Battle hots up}

Mercury, the private telecomminications network licensed last year in Britain to compete with British Telecom, the still-public network, is about to take off rather sooner than expected. Its founders (Cable and Wireless, British Petroleum and Barclays Bank) have brought foward to next spring the launch of a service in London, intended as the firs element in a more extensive network.

Mercury says that demand fron potential customers is the chief reason why its plans have been advanced, but thee seems no doubt that the competitiveness of British Telecom is another. At the outst, Mercury hopes to gain some advantage because it will be offering high-speed digital transmission services, available from British Telecom only in the City of London. The plan is to do for Birmingham by next May what will have been done ir London a little earlier, when the two citie: will be linked by microwave. These twc services are the first elements in what Mercury misleadingly calls a national network. The present goal (for 1984) is a figure-of-eight network linking only the major commercial cities in central England. Initially transmission within cities will be by microwave radio.

Initially, Mercury will be suitable only for customers wishing to send voice and data down leased lines at 64 kilobits or : megabits a second. Charges will be baset on standard rates per channel, independert of distance. The basic network is expected

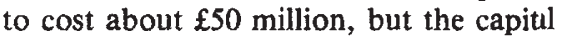
cost of providing a network to compee with British Telecom's will be far more. Investment of $£ 1,000$ million over 25 yeirs has been mentioned to pay for, amang other services, switching and possibly a lnk with British Telecom.

But plans for the future will depenc on customer demand. Mercury is in tuch with 25 potential customers for its Lordon service, and government departmens as well as large companies are said to be showing interest. Mercury believes thit its chief attraction over British Teleom's digital service in London will b: its transatlantic satellite-link. At one sage, plans for international links had semed doomed to be obstructed by Bitish Telecom which, as the signatoy to Intelsat, is the recognized internaional carrier. But Mercury, which wil be negotiating directly with Intelsat tocarry traffic late next year from London, is unperturbed that British Telecom must sign the contract, seeing British Telıcom's involvement as purely administrative.

How successful Mercury is in attacting its statutory allowance of 3 per tent of British Telecom's business by 1985 vill also depend on the competition. The consensus is that the monopoly is putting the leat on.

Judy Redfearn 